\title{
Large-scale space use of large juvenile and adult smalltooth sawfish Pristis pectinata: implications for management
}

\author{
Jasmin Graham ${ }^{1, *}$, Andrea M. Kroetz ${ }^{2}$, Gregg R. Poulakis ${ }^{3}$, Rachel M. Scharer ${ }^{3}$, \\ John K. Carlson ${ }^{4}$, Susan Lowerre-Barbieri ${ }^{5,6}$, Danielle Morley ${ }^{7}$, Eric A. Reyier ${ }^{8}$, \\ R. Dean Grubbs ${ }^{1}$
}

\footnotetext{
${ }^{1}$ Florida State University Coastal and Marine Laboratory, St. Teresa, Florida 32358, USA

${ }^{2}$ Riverside Technology, Inc. for NOAA, National Marine Fisheries Service, Southeast Fisheries Science Center, Panama City, Florida 32408, USA

${ }^{3}$ Charlotte Harbor Field Laboratory, Fish and Wildlife Research Institute, Florida Fish and Wildlife Conservation Commission, Port Charlotte, Florida 33954, USA

${ }^{4}$ NOAA, National Marine Fisheries Service, Southeast Fisheries Science Center, Panama City, Florida 32408, USA

${ }^{5}$ Fisheries and Aquatic Sciences Program, University of Florida, 7922 NW 71st Street, Gainesville, Florida 32653, USA

${ }^{6}$ Fish and Wildlife Research Institute, Florida Fish and Wildlife Conservation Commission, St. Petersburg, Florida 33701, USA

${ }^{7}$ South Florida Regional Laboratory, Fish and Wildlife Research Institute,

Florida Fish and Wildlife Conservation Commission, Marathon, Florida 33050, USA

${ }^{8}$ Herndon Solutions Group, LLC, NASA Environmental and Medical Contract, Kennedy Space Center, Florida 32899, USA
}

\begin{abstract}
The smalltooth sawfish Pristis pectinata is an endangered species endemic to the Atlantic Ocean. The only known viable populations occur in the USA along both coasts of Florida and in the western Bahamas. Little is known about habitat use and movement ecology of large juvenile and adult smalltooth sawfish. Although Critical Habitat - a management designation in the USA - has been identified for small juveniles, it has yet to be identified for these life stages. Between May 2016 and April 2019, we used passive acoustic telemetry and 3 large data sharing networks of receivers to track movements of 43 large juvenile and adult smalltooth sawfish. During this study, 24 females and 19 males were implanted with transmitters with estimated 4 or $10 \mathrm{yr}$ battery lives. These tagged individuals were detected off the southeastern USA on 461 receivers ranging from off the coast of Brunswick, Georgia, to the lower Florida Keys, and along the Gulf coast to Apalachee Bay, Florida. Seasonal migrations were undertaken by 58\% (43\% mature; $57 \%$ immature) of the tagged individuals, with the remainder being apparent residents of their tagging locations. Tagged sawfish from both size classes and of both sexes migrated, which indicates that neither sex nor length is a predictor of whether a sawfish will migrate or not. Although both coasts of Florida were used for migration, most individuals consistently used the same coast when they migrated. The areas surrounding Boca Grande, Cape Canaveral, and the lower Florida Keys were heavily visited sites that could be further evaluated as potential Critical Habitat for these life stages. Understanding the movement patterns of this Critically Endangered species is essential for creating policies to protect areas important for promoting growth of the population.
\end{abstract}

KEY WORDS: Pristis pectinata - Habitat use - Acoustic monitoring - Endangered species · Conservation · Management 


\section{INTRODUCTION}

Sawfishes are one of the most endangered families of elasmobranchs in the world (Dulvy et al. 2014). The smalltooth sawfish Pristis pectinata is listed as endangered under the US Endangered Species Act (ESA). Although the species was historically distributed in coastal habitats throughout much of the Gulf of Mexico and along the east coast of the USA, over the past 100 yr the population has declined dramatically due to both targeted and bycatch overfishing (Carlson et al. 2013, Brame et al. 2019). In addition to fishing mortality, the smalltooth sawfish faces other threats such as habitat loss and anthropogenic perturbations (Seitz \& Poulakis 2006). The only remaining viable population in the USA, considered to be a 'lifeboat' population (Dulvy et al. 2014), is centered in southwest Florida from Charlotte Harbor to the Florida Keys (NMFS 2009, Norton et al. 2012).

The smalltooth sawfish was listed under the ESA in 2003, which afforded it protection and mandated that a recovery plan be created to identify and mitigate threats to the remaining population. One of the major threats that the recovery plan addresses is habitat loss, particularly in those areas designated as Critical Habitat under the ESA. Critical Habitat, as defined by the ESA, encompasses areas inside or outside a species' range where there are physical and biological features essential to the conservation of the species that may require special protections (NMFS 2009). In most circumstances, Critical Habitat must be designated for ESA-listed species at the time of listing or within 1 additional year; it can also be divided by life history stage if warranted. Although Critical Habitat was designated for small juvenile smalltooth sawfish ( $<2 \mathrm{~m}$ total length) in 2009 (Norton et al. 2012), Critical Habitat for larger juveniles $(>2 \mathrm{~m})$ and adults (males $>3.4 \mathrm{~m}$, females $>3.7 \mathrm{~m}$; Brame et al. 2019) has yet to be identified and remains a recovery priority.

Smalltooth sawfish, like many elasmobranch species, exhibit ontogenetic habitat shifts (Grubbs 2010). While small juveniles exhibit high site fidelity and spend nearly all their time in the shallow waters along mangrove shorelines (Poulakis et al. 2011, 2013, Hollensead et al. 2016, 2018), leaving shorelines occasionally to feed (Lear et al. 2019a), larger juveniles and adults are known to use deeper water within and beyond estuaries (Poulakis \& Seitz 2004, Waters et al. 2014). Some studies, such as those by Carlson et al. (2014) and Papastamatiou et al. (2015), have explored the movements of larger sawfish, though the conclusions of these studies were limited both spatially and temporally. Nevertheless, Carlson et al. (2014) found that females demonstrated seasonal movement patterns and showed the greatest movement in fall and winter. Papastamatiou et al. (2015) observed seasonal movements in some individuals, but no clear seasonal movement pattern was distinguishable. Although large juvenile and adult smalltooth sawfish have been observed moving into deeper waters, little research has been conducted to understand these movement patterns, the durations spent in specific areas, or if all individuals have similar patterns. The lack of data on larger individuals has made it difficult to accurately assess habitat use patterns and any threats associated with the areas they inhabit.

Much of what is known about large juvenile and adult smalltooth sawfish distribution comes from analyses of encounter reports in Florida. Poulakis \& Seitz (2004) found that larger sawfish occurred in shallow water $(<10 \mathrm{~m})$, although about one-third of encounters occurred in deep water in south Florida, especially off the ocean side of the Florida Keys, at depths up to $70 \mathrm{~m}$ (max.: $122 \mathrm{~m}$ ). Similarly, Wiley \& Simpfendorfer (2010) suggested that while large juvenile and adult smalltooth sawfish spend a considerable amount of time in deeper waters $(>5 \mathrm{~m})$, they also use shallower waters. More recently, Waters et al. (2014) concluded that estimated length increased with increasing depth across much of the state, except for southeast Florida where large juvenile and adult sawfish were reported at all depths. So, the consensus among these studies is that large juvenile and adult sawfish occur across a broad range of depths. While these conclusions are useful, long-term tagging studies are needed to better understand hypothesized ontogenetic habitat shifts. Not much is known about the migration patterns of the smalltooth sawfish; however, Carlson et al. (2014) observed differences in male and female movement patterns. Feldheim et al. (2017) showed that females reproduce biennially and hypothesized that this reproductive cycle could drive female movement patterns.

The current study investigated the movements of large juvenile and adult smalltooth sawfish by taking advantage of increased use of internally implanted acoustic tags and widespread use of acoustic receivers along the Florida coastline. Large-scale tracking employing acoustic data from 3 data-sharing networks was used to identify high-use areas for these life stages and identify any differences in habitat use across sawfish demographics. The identification of high-use areas may help policy makers support the recovery of the US population of the smalltooth sawfish. 


\section{MATERIALS AND METHODS}

\subsection{Study area and acoustic receiver arrays}

Large juvenile ( $>2 \mathrm{~m}$ stretch total length [STL]) and adult ( $>3.4 \mathrm{~m}$ for males; $>3.7 \mathrm{~m}$ for females; Brame et al. 2019) smalltooth sawfish were tagged in the greater Charlotte Harbor area, which encompasses the Caloosahatchee River, Peace River and Boca Grande regions, Everglades National Park and the surrounding Florida Bay, the Florida Keys, and off the east coast near Ft. Pierce, Florida (Fig. 1). Passive acoustic telemetry was used to track tagged individuals. This is a technique that uses acoustic receivers (e.g. VR2W, VR2-Tx; Vemco/Innovasea) arranged in arrays to detect signals from coded transmitters. The detection range of receivers is variable and can range from a radius of $<100 \mathrm{~m}$ to more than $500 \mathrm{~m}$ depending on factors such as water depth, turbidity, sea state, and bottom type (Collins et al. 2008, Huveneers et al. 2016, Mourier et al. 2017).

For monitoring sawfish, arrays of acoustic receivers were established within the Charlotte Harbor estuarine system: 48 receivers, including 2 Vemco Position-

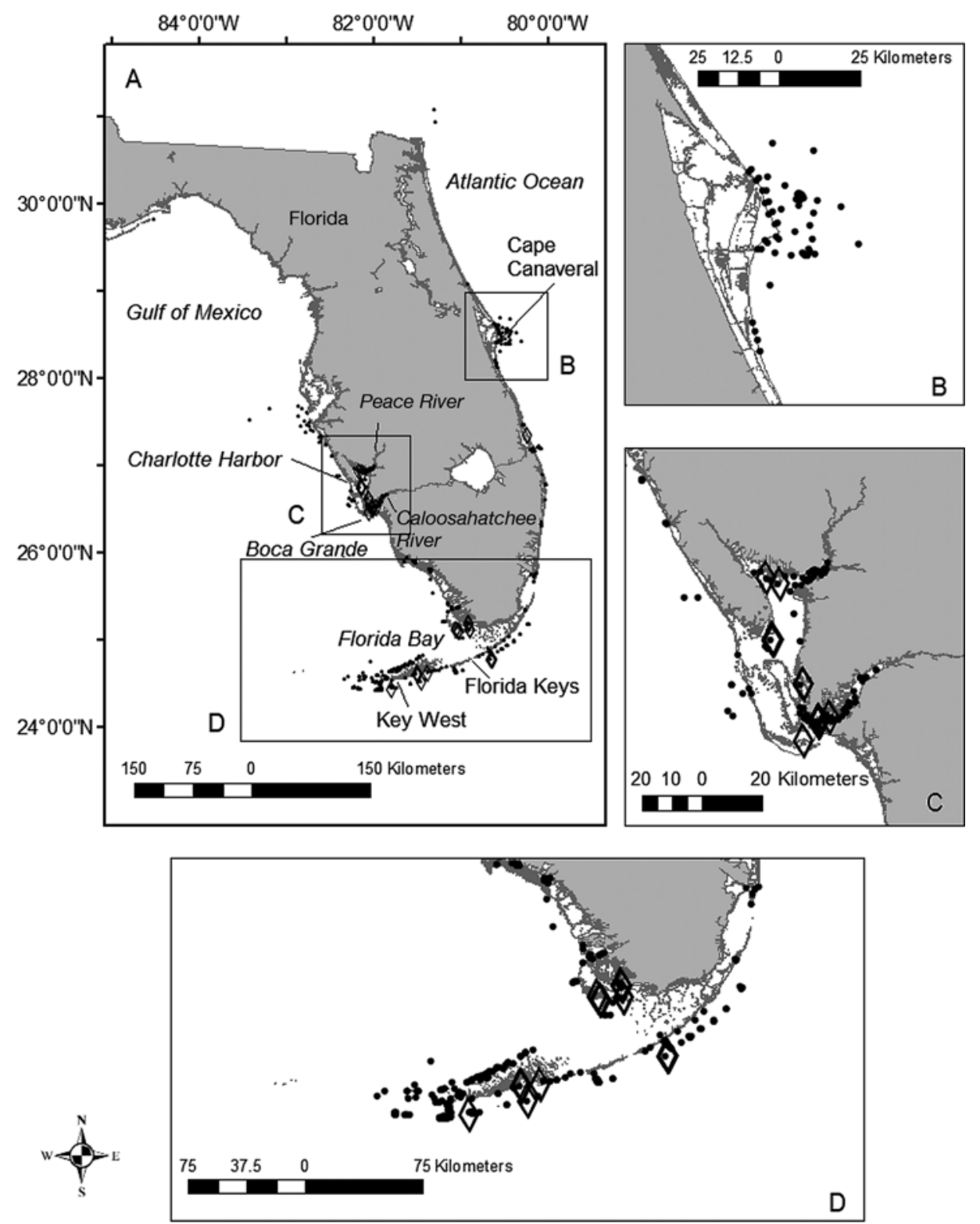

Fig. 1. Map, with insets, of waters off the southeastern USA where smalltooth sawfish Pristis pectinata were studied between May 2016 and April 2019. Points: acoustic receivers where detections occurred $(\mathrm{n}=461$ ); diamonds: tagging locations. (A) Overall study area, (B) Cape Canaveral, (C) Charlotte Harbor, and (D) Everglades National Park and the Florida Keys 
ing Systems (VPS) that included VR2-Tx receivers, in the northern portion of the system in and near the Peace River, and 52 receivers, including 1 VPS, in the southern portion of the system in and near the Caloosahatchee River and Boca Grande. Additionally, 26 receivers were dispersed throughout the Everglades National Park and Keys regions (Fig. 1). In addition, $>2000$ receivers from the Florida Atlantic Coast Telemetry (FACT), Atlantic Cooperative Telemetry (ACT), and Integrated Tracking of Aquatic Animals in the Gulf of Mexico (iTAG) networks were available to collect data on sawfish movements. These networks provided access to hundreds of receivers along the Gulf and Atlantic coasts of Florida and southern Georgia maintained by various organizations and researchers. Receiver data were downloaded on various schedules at the discretion of the research organization to which they belonged. We specifically contacted researchers with receivers in our study area to maximize the amount of data collected.

\subsection{Field sampling and tagging}

Individuals tracked in this study were captured and tagged using a combination of field techniques. Sampling occurred in all months from May 2016 to April 2019, and sampling sites were selected based on research plans among the collaborators. In Charlotte Harbor, sawfish were caught using rod and reel or drumlines. Rod and reel gear used 36-45 kg (80$100 \mathrm{lb}$ ) test monofilament or braided line and 9/0 nonoffset circle hooks. Drumlines used $249 \mathrm{~kg}$ (550 lb) test monofilament with a single 14/0 non-offset circle hook. They were anchored using $20 \mathrm{~kg}$ (45 lb) concrete blocks and 5 or $10 \mathrm{~m}$ gangions depending on water depth. Drumlines were fished for $1 \mathrm{~h}$, and up to 5 were set at a time. Rod and reel gear was used while the drumlines fished. Both gears primarily used ladyfish Elops saurus for bait.

Sawfish captured in shoreline areas of Everglades National Park were caught with scientific gillnets consisting of $7.6 \mathrm{~cm}$ (3 inch) or $10.2 \mathrm{~cm}$ (4 inch) stretch mesh. Gillnets were $1.5 \mathrm{~m}$ deep, either 30.5 $(100 \mathrm{ft})$ or $61 \mathrm{~m}(200 \mathrm{ft})$ long. Gillnets were set one at a time and perpendicular to the coastline. Gillnets soaked for a minimum of $1 \mathrm{~h}$, were continuously monitored, and completely checked every $0.5 \mathrm{~h}$.

In Florida Bay and the Florida Keys, sawfish were captured using a bottom set longline approximately $750 \mathrm{~m}$ in length consisting of fifty $2.5 \mathrm{~m}$ gangions composed of $3.2 \mathrm{~mm}, 363 \mathrm{~kg}$ (800 lb) test monofilament terminated in 16/0 non-offset circle hooks baited with ladyfish. Longlines were almost always set in pairs and soaked for approximately $1 \mathrm{~h}$.

Smalltooth sawfish on the east coast of Florida were opportunistically tagged after being caught in the intake canal of the Florida Power and Light St. Lucie Nuclear Power Plant. The intake canal includes nets to prevent sea turtles from being entrained into the power plant; however, sawfish are also occasionally caught.

Upon capture, each smalltooth sawfish was sexed, rostrum length and STL measured, and rostral tooth counts recorded. Depending on length, a $69 \mathrm{kHz}$ Vemco/Innovasea V13-1L or a V16-6H acoustic transmitter with either an estimated 4 or 10 yr battery life, respectively, was internally implanted into the body cavity of each sawfish through a small incision on the ventral side of the animal. The incision was closed using 2 or 3 dissolvable sutures. Observations of 3 recaptured individuals show that incisions healed completely within $25 \mathrm{~d}$ with minimal scarring (G. R. Poulakis unpubl. data). The transmitters were programmed to emit a unique acoustic code on a random delay once every 80-180 s (V13) or 70-150 s (V16). Delays were used to minimize signal collisions and maximize battery life.

\subsection{Data analysis}

Network analysis was used to determine the significance of areas based on how sawfish moved throughout the study area. There were 2 main objectives for this analysis: the first was to build directed movement networks based on the acoustic telemetry data and the second was to compare regional importance by analyzing the node metrics within the different movement networks. Directed movement networks were built based on approximately 140000 detections on 461 receivers. The data were processed by removing single detections and binning the data by day to deemphasize the influence of individuals that spent long periods of time near receivers. Receivers were grouped into clusters, henceforth referred to as 'regions.' These regions were formed based on spatial proximity. It is important to note that the Peace River and Caloosahatchee River regions were defined as the areas between the banks of the rivers and their respective mouths. The Boca Grande region was defined as the coastal area outside the Charlotte Harbor estuary. When building the networks, nodes were defined as regions, while edges were represented by the movement of an individual from one region to another. An edge list for all indi- 
viduals, females, males, immature (large juveniles), and mature sawfish was created as well as edge lists for each season (winter: December-February; spring: March-May; summer: June-August; fall: September-November). Edge lists were created by ordering the movements of each individual and counting the number of movements between nodes using the $\mathrm{R}$ statistical platform (R Core Team 2019) and Python. Directed networks were created from each edge list using the 'igraph' (Csardi \& Nepusz 2006), 'ggraph' (https://github.com/thomasp85/ggraph), and 'ggmap' (Kahle \& Wickham 2013) packages in R.

The degree, strength, page rank centrality, and betweenness of each node was analyzed in every network to identify regions of importance. Comparisons of mean degree, centrality, and betweenness were made across the sex and maturity networks using a Wilcoxon rank test to determine if there were any significant differences between sexes or between immature and mature sawfish. A similar comparison across seasons was conducted using a Kruskal-Wallis $H$-test to determine if there were any significant differences.

\section{RESULTS}

From May 2016 through April 2019, 24 female (2.12$4.53 \mathrm{~m} \mathrm{STL}$ ) and 19 male (2.11-4.07 m STL) smalltooth sawfish $(\mathrm{n}=43)$ over $2 \mathrm{~m}$ long were implanted with acoustic transmitters (Table 1). These smalltooth sawfish were detected on 461 acoustic receivers ranging from off the coast of Brunswick, Georgia, to the lower Florida Keys and along the eastern Gulf of Mexico coast to Apalachee Bay, Florida. Tracking time, as measured by the time between the first and last detection, averaged approximately 13 mo. There was a large range in tracking time, with some sawfish having as little as 1 mo between their first and last detection and others having as much as $3 \mathrm{yr}$. Some individuals had many more detections than others (Table 1). All sawfish tagged in Charlotte Harbor were large juveniles and thus tagging location and maturity were linked. Large juvenile sawfish tended to be more localized and therefore have higher detection rates in all months (Fig. 2). The receiver density in Charlotte Harbor, where these sawfish were spending much of their time, was high due to the targeted deployment of receivers for monitoring estuarine habitats. Seasonally, the highest number of detections occurred in the spring and early summer (Fig. 2). By region, the highest numbers of detections were in portions of the core range where receiver density was highest, such as the Peace River, Caloosahatchee River, and Florida Keys (Fig. 3).

\subsection{Sawfish tagged in Charlotte Harbor}

Of the 19 sawfish tagged (all large juveniles) in the Charlotte Harbor estuarine system, 8 were considered apparent residents (hereafter 'residents'), while the other 11 left the system at some point and were classified as apparent migrants (hereafter 'migrants'). Three immature females and 1 immature male used the Caloosahatchee River exclusively. One immature male used the Peace River exclusively, and 2 immature males used the Caloosahatchee River and Boca Grande regions. One immature female used both the Peace River and Caloosahatchee River regions. These 8 sawfish were considered residents because they were never detected north or south of the Charlotte Harbor estuarine system and were between 2.11 and $2.66 \mathrm{~m}$ STL. The rest of the sawfish tagged in Charlotte Harbor left the system at some point during their tracking period and ranged from $2.13-3.20 \mathrm{~m}$ STL. The migrants were significantly larger than the residents $(t$-test, $t=2.73, \mathrm{df}=17, \mathrm{p}=0.01)$. The average time the migrant sawfish spent in their respective rivers post-tag-and-release was about $4 \mathrm{mo}$, with some sawfish detected south of the estuary within 1 mo of release, and others after about 9 mo. One of the smallest of the migrants was detected on receivers offshore of the Tampa Bay region. Other migrants were detected in the Tampa Bay region as well as regions further south, such as the Florida Bay and Florida Keys region.

While nearly all the migrant sawfish tagged in Charlotte Harbor moved south upon exiting the Charlotte Harbor estuarine system, 1 immature female went north to the Venice region in January and returned to Charlotte Harbor shortly after. Most migrant sawfish used the Florida Bay area and primarily the lower Florida Keys after leaving Charlotte Harbor. The migrant sawfish tagged in Charlotte Harbor left the estuary between October and January. Three migrants returned to the estuary in May.

\subsection{Sawfish tagged in Everglades National Park and the Florida Keys}

Of the 21 sawfish tagged in Everglades National Park and Florida Keys area, 7 remained in their tagging areas and were considered residents. This group was made up of 1 immature female, 3 mature 
Table 1. Demographic data of smalltooth sawfish Pristis pectinata including ID, sex (F: female; M: male), maturity, stretch total length (STL), tagging location, movement classification (resident: apparent resident; migrant: apparent migrant), and detection-related data. Number of detections corresponds to the raw number of detections before binning by day. Dates are given as dd/mm/yyyy. CH: Charlotte Harbor; EC: east coast; ENP: Everglades National Park; Keys: Florida Keys; N/A: data deficient

\begin{tabular}{|c|c|c|c|c|c|c|c|c|c|}
\hline ID & Maturity & $\begin{array}{l}\text { STL } \\
(\mathrm{m})\end{array}$ & $\begin{array}{l}\text { Location } \\
\text { tagged }\end{array}$ & $\begin{array}{l}\text { Movement } \\
\text { class }\end{array}$ & Date tagged & $\begin{array}{c}\text { Date of first } \\
\text { detection }\end{array}$ & $\begin{array}{c}\text { Date of last } \\
\text { detection }\end{array}$ & $\begin{array}{l}\text { Days of } \\
\text { study }\end{array}$ & $\begin{array}{c}\text { No. of } \\
\text { detections }\end{array}$ \\
\hline F1 & Immature & 2.12 & $\mathrm{CH}$ & Resident & 15/03/2019 & 15/03/2019 & 18/09/2019 & 188 & 4639 \\
\hline $\mathrm{F} 2$ & Immature & 2.13 & $\mathrm{CH}$ & Migrant & 02/08/2018 & 03/08/2018 & 03/10/2019 & 427 & 31954 \\
\hline F3 & Immature & 2.16 & Keys & N/A & 10/08/2017 & 11/03/2018 & 26/06/2018 & 108 & 35 \\
\hline $\mathrm{F} 4$ & Immature & 2.25 & ENP & N/A & $20 / 06 / 2016$ & 05/01/2018 & 04/02/2018 & 31 & 53 \\
\hline F5 & Immature & 2.27 & $\mathrm{CH}$ & Resident & 15/03/2019 & 15/03/2019 & 14/09/2019 & 184 & 2138 \\
\hline F6 & Immature & 2.34 & $\mathrm{CH}$ & Migrant & $19 / 07 / 2017$ & $21 / 07 / 2017$ & $25 / 06 / 2019$ & 705 & 3543 \\
\hline F7 & Immature & 2.38 & $\mathrm{CH}$ & Resident & 25/03/2019 & $25 / 03 / 2019$ & 20/09/2019 & 180 & 3808 \\
\hline F8 & Immature & 2.43 & $\mathrm{CH}$ & Resident & 09/07/2018 & 09/07/2018 & 10/09/2019 & 64 & 8768 \\
\hline F9 & Immature & 2.46 & $\mathrm{CH}$ & Migrant & $26 / 07 / 2017$ & 26/07/2017 & 26/04/2018 & 275 & 1246 \\
\hline F10 & Immature & 2.57 & $\mathrm{CH}$ & Migrant & $26 / 07 / 2017$ & $26 / 07 / 2017$ & $23 / 07 / 2018$ & 363 & 1927 \\
\hline F11 & Immature & 2.58 & $\mathrm{CH}$ & Resident & $20 / 03 / 2019$ & $20 / 03 / 2019$ & $29 / 07 / 2019$ & 132 & 5381 \\
\hline F12 & Immature & 2.69 & $\mathrm{CH}$ & Migrant & $12 / 09 / 2018$ & 12/09/2018 & $26 / 12 / 2018$ & 106 & 157 \\
\hline F13 & Immature & 3.18 & ENP & Migrant & $30 / 03 / 2017$ & $16 / 11 / 2017$ & $22 / 06 / 2019$ & 584 & 864 \\
\hline F14 & Immature & 3.20 & $\mathrm{CH}$ & Migrant & $11 / 08 / 2017$ & $15 / 08 / 2017$ & $21 / 05 / 2019$ & 645 & 1940 \\
\hline F15 & Immature & 3.49 & Keys & Migrant & 01/08/2018 & $27 / 08 / 2018$ & 08/06/2019 & 286 & 166 \\
\hline F16 & Immature & 3.55 & Keys & Migrant & $11 / 04 / 2017$ & $16 / 04 / 2017$ & 03/02/2018 & 294 & 1279 \\
\hline F17 & Mature & 3.64 & Keys & Migrant & $11 / 04 / 2017$ & $27 / 04 / 2017$ & 28/03/2019 & 701 & 4913 \\
\hline F18 & Mature & 3.71 & $\mathrm{EC}$ & Migrant & 02/11/2017 & $23 / 11 / 2017$ & 10/04/2019 & 504 & 2069 \\
\hline F19 & Mature & 3.92 & Keys & Migrant & 01/04/2017 & 01/04/2017 & $25 / 05 / 2019$ & 785 & 755 \\
\hline F20 & Mature & 4.26 & Keys & Migrant & $01 / 04 / 2017$ & 03/04/2017 & $28 / 05 / 2019$ & 786 & 610 \\
\hline F21 & Mature & 4.38 & Keys & Migrant & $21 / 05 / 2016$ & $21 / 05 / 2016$ & $01 / 06 / 2019$ & 1107 & 3122 \\
\hline F22 & Mature & 4.38 & ENP & Resident & 13/09/2016 & 05/11/2016 & 04/04/2019 & 881 & 1548 \\
\hline F23 & Mature & 4.42 & ENP & Resident & 02/04/2017 & $12 / 05 / 2017$ & 19/03/2019 & 677 & 791 \\
\hline F24 & Mature & 4.53 & ENP & N/A & 02/04/2017 & 04/06/2017 & $06 / 06 / 2017$ & 3 & 27 \\
\hline M1 & Immature & 2.11 & $\mathrm{CH}$ & Resident & 04/06/2018 & 05/06/2018 & 27/03/2019 & 296 & 5769 \\
\hline M2 & Immature & 2.35 & $\mathrm{CH}$ & Resident & $21 / 08 / 2018$ & $21 / 08 / 2018$ & $18 / 09 / 2019$ & 394 & 10288 \\
\hline M3 & Immature & 2.35 & $\mathrm{CH}$ & Resident & $26 / 07 / 2017$ & $26 / 07 / 2017$ & $19 / 04 / 2019$ & 633 & 3118 \\
\hline M4 & Immature & 2.48 & $\mathrm{CH}$ & Resident & $21 / 08 / 2018$ & $21 / 08 / 2018$ & 14/09/2019 & 390 & 12509 \\
\hline M5 & Immature & 2.59 & ENP & Resident & $09 / 11 / 2016$ & $21 / 01 / 2018$ & $16 / 06 / 2019$ & 512 & 277 \\
\hline M6 & Immature & 2.72 & ENP & Migrant & $30 / 03 / 2017$ & $26 / 04 / 2017$ & 08/06/2019 & 774 & 10337 \\
\hline M7 & Immature & 2.76 & $\mathrm{CH}$ & Migrant & $24 / 10 / 2017$ & 19/07/2017 & $22 / 04 / 2019$ & 643 & 919 \\
\hline M8 & Immature & 2.60 & $\mathrm{CH}$ & Migrant & $23 / 10 / 2018$ & $23 / 10 / 2018$ & 24/04/2019 & 184 & 237 \\
\hline M9 & Immature & 2.66 & $\mathrm{CH}$ & Migrant & 18/04/2019 & 18/04/2019 & 26/09/2019 & 162 & 2615 \\
\hline M10 & Immature & 2.90 & $\mathrm{CH}$ & Migrant & $12 / 09 / 2018$ & $12 / 09 / 2018$ & $22 / 04 / 2019$ & 223 & 2229 \\
\hline M11 & Immature & 2.93 & Keys & Migrant & $20 / 07 / 2016$ & $22 / 08 / 2016$ & $10 / 06 / 2019$ & 74 & 4284 \\
\hline M12 & Mature & 3.50 & $\mathrm{EC}$ & Migrant & $17 / 09 / 2017$ & $24 / 09 / 2017$ & $12 / 08 / 2018$ & 323 & 638 \\
\hline M13 & Mature & 3.82 & ENP & N/A & $06 / 04 / 2019$ & $10 / 04 / 2019$ & $15 / 06 / 2019$ & 67 & 25 \\
\hline M14 & Mature & 3.83 & Keys & Migrant & $01 / 04 / 2017$ & $01 / 04 / 2017$ & $17 / 06 / 2019$ & 808 & 689 \\
\hline M15 & Mature & 3.98 & Keys & Migrant & $15 / 04 / 2018$ & $14 / 02 / 2018$ & $30 / 11 / 2018$ & 290 & 382 \\
\hline M17 & Mature & 3.98 & ENP & Migrant & $02 / 04 / 2017$ & $26 / 04 / 2017$ & $07 / 04 / 2019$ & 712 & 388 \\
\hline M18 & Mature & 3.98 & ENP & Resident & 09/09/2016 & $12 / 12 / 2016$ & $28 / 05 / 2019$ & 898 & 2414 \\
\hline M19 & Mature & 4.07 & Keys & Migrant & $14 / 04 / 2017$ & $15 / 04 / 2017$ & $02 / 07 / 2017$ & 79 & 1143 \\
\hline
\end{tabular}

females, 1 immature male, and 2 mature males. Ten individuals left the area and moved north at some point during their tracking periods. These sawfish were considered migrants because they had detection days outside of the region. This group included 1 immature female, 3 mature females, 2 immature males, and 4 mature males. There was no difference in lengths between residents and migrants tagged in the Florida Keys or Everglades National Park regions $(t=0.34, \mathrm{df}=19, \mathrm{p}=0.73)$.
Two immature males and 2 mature females traveled up the Gulf coast of Florida whereas 5 sawfish, each a different sex or life stage, traveled up the east coast of Florida. There was no difference in lengths between the sawfish that emigrated up the east coast and those that emigrated up the Gulf coast $(t=0.39$, $\mathrm{df}=7, \mathrm{p}=0.71$ ).

The migrant sawfish tagged in the Florida Keys migrated mostly to the Tampa Bay or Charlotte Harbor regions on the Gulf coast and to the Cape 


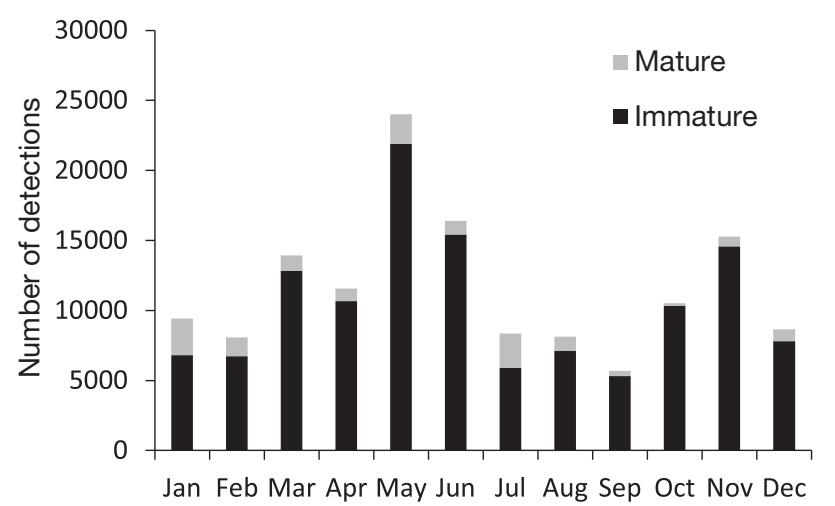

Fig. 2. Distribution of total smalltooth sawfish Pristis pectinata acoustic detections by month and life stage throughout the study period (May 2016-April 2019)

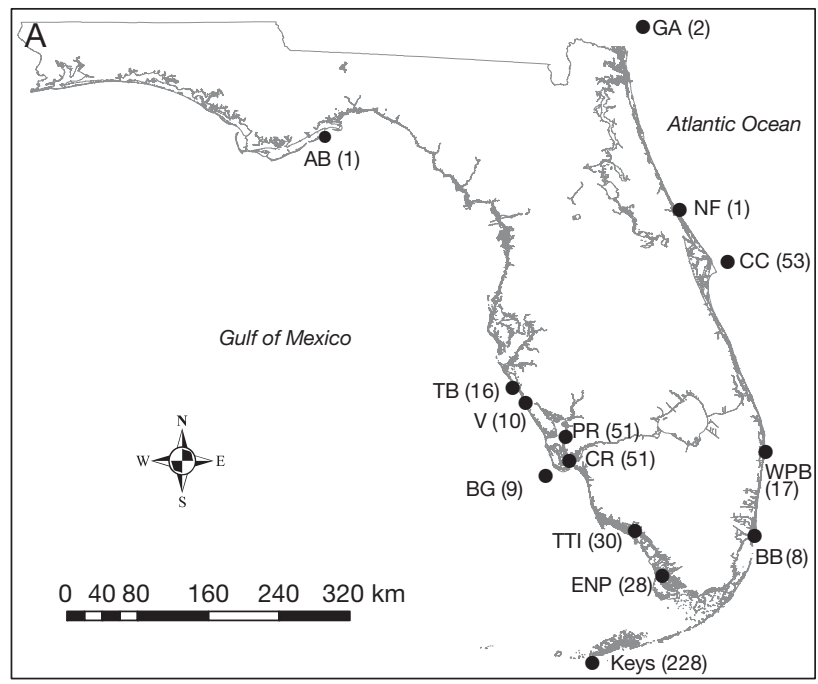

B

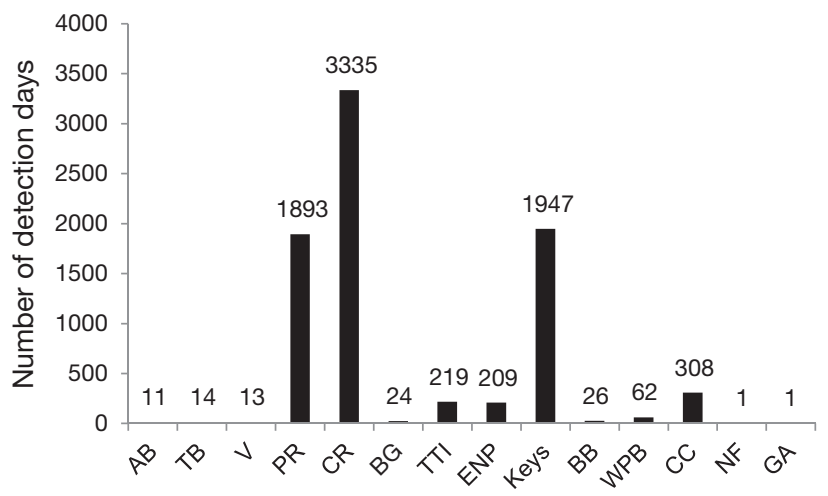

Fig. 3. (A) Location of all 14 regions used for analysis. Numbers in parentheses: number of acoustic receivers in each region where sawfish were detected. (B) Number of smalltooth sawfish Pristis pectinata detection days by region. Numbers above each region: number of detection days across all individuals detected in that region. AB: Apalachee Bay; TB: Tampa Bay; V: Venice; PR: Peace River; CR: Caloosahatchee River; BG: Boca Grande; TTI: Ten Thousand Islands; ENP: Everglades National Park; Keys: Florida Keys; BB: Biscayne Bay; WPB: West Palm Beach; CC: Cape Canaveral; NF: North Florida; GA: Georgia
Canaveral region on the east coast. However, 2 adult males traveled much farther north to the Georgia and Apalachee Bay regions. Most migrants began moving north in May or June and started their journey south again in the fall, regardless of coast. The time frame in which the sawfish began moving back south was more varied than the time frame when they started moving north.

The movements of 1 mature female and 1 mature male deviated from the above pattern. One mature female (4.26 m STL) migrated up the Gulf coast in 2017 but moved up the east coast the following year. A mature male (3.83 $\mathrm{m}$ STL) that also used both coasts and was detected on the same array of receivers off Cape Canaveral 3 yr in a row exhibited a unique movement pattern: he began his movements up the east coast earlier than the other migrant individuals, but switched direction and migrated up the Atlantic and then the Gulf coast during the same 2017 migration period (Fig. 4). This individual was not detected on any receivers between his last detection in the Florida Keys on 29 May 2017 and his series of detections on a receiver in the Tampa Bay region on 12 September 2017. He then made the migration from the Tampa Bay region to the Florida Keys region in just 1 wk. Due to the lack of detections of this sawfish between May and September of that year, it is unclear how much time he spent in the Florida Keys region versus the Tampa Bay region.

\subsection{Sawfish tagged off the east coast}

Two adult sawfish, 1 of each sex, were tagged off the east coast of Florida. They were both tagged in fall and began moving south that season. These sawfish then began moving north again the following summer, consistent with the movements of the migrant individuals tagged in the Florida Keys and Everglades National Park.

\subsection{Network analysis}

Network analysis was conducted using detection data from May 2016 to June 2019. The total network (Fig. 5) had a mean path length of 1.83 and edge density of 0.32 , both indications of randomness of movement. Individual node metrics were assessed to identify potentially important regions for sawfish (Table 2). The Florida Keys, Cape Canaveral, and Boca Grande regions had the highest degree centrality as well as 


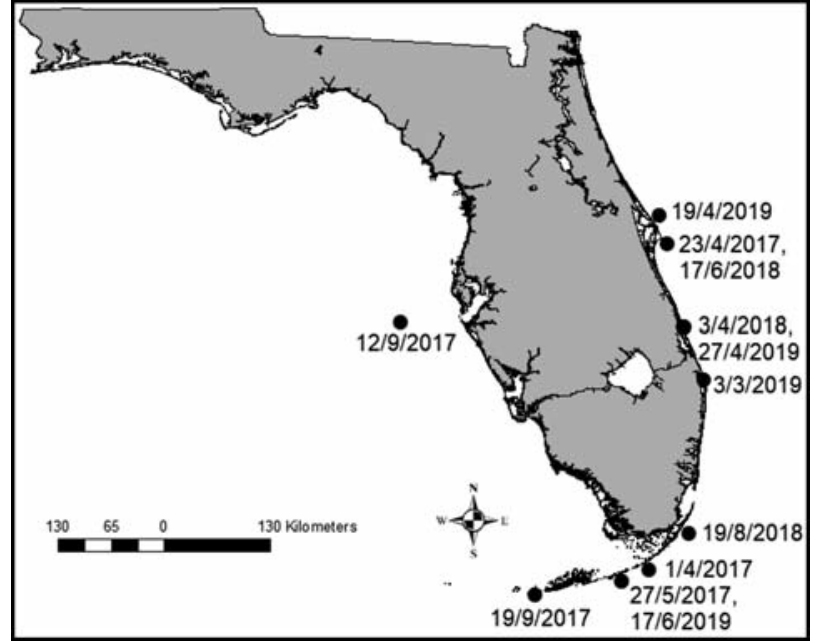

Fig. 4. Movements made along both coasts of Florida by an adult male smalltooth sawfish Pristis pectinata (M14; $3.83 \mathrm{~m}$ stretch total length). Dates indicate detections in new regions

the highest betweenness scores. The regions with the highest node strength were the Florida Keys and Everglades National Park, indicating that these regions had a high frequency of movements to and from them. The Florida Keys, Everglades National Park, and Caloosahatchee River regions had the highest page rank centrality, indicating that not only are these regions important, but also that they are directly connected to other regions of high importance. Of all south Florida nodes, Biscayne Bay scored the lowest on all metrics, followed by West Palm Beach, indicating that sawfish only pass through these regions during movements from the Florida Keys and Everglades National Park nodes to and from Cape Canaveral.

When comparing the networks by sex, males and females moved in similar ways (Fig. 6, Table 3). The Florida Keys and Caloosahatchee River regions were important to both sexes. Males and females used the Florida Keys and Cape Canaveral regions as they traveled between nodes, but females also used the Boca Grande node heavily as a movement corridor. Only males moved north of these core areas on the Atlantic and Gulf coasts. However, a Wilcoxon rank test showed no significant difference between mean degree $(p=0.329)$, betweenness $(p=0.513)$, or page rank centrality $(p=0.734)$ between males and females, indicating that there was no significant difference in their movements.

When comparing the immature and mature networks, it was apparent that mature sawfish moved farther north than immature sawfish, although the

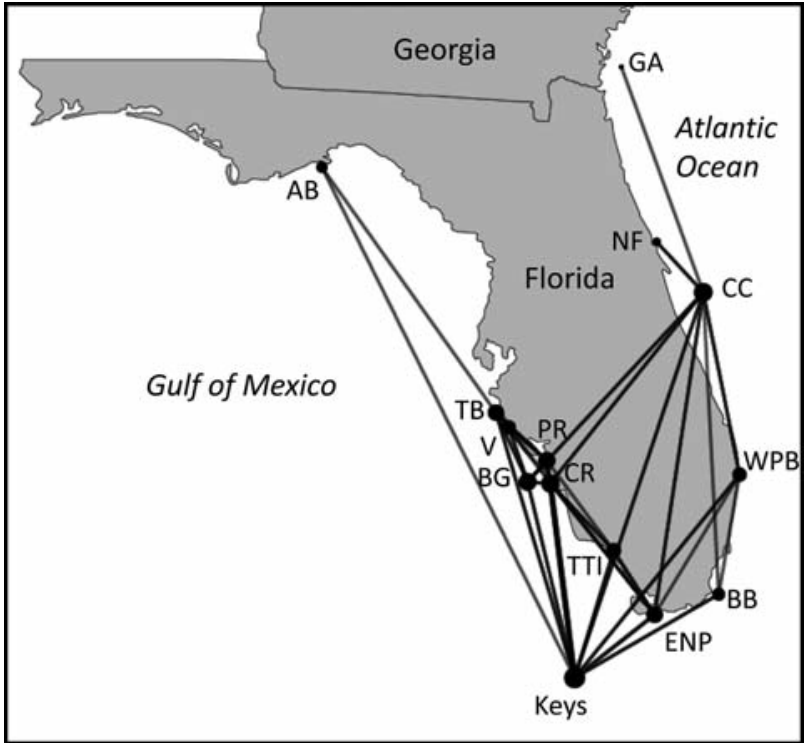

Fig. 5. Network map for all smalltooth sawfish Pristis pectinata tagged in this study. Node size is proportional to node strength; line width is proportional to edge weight. Nodes are positioned based on the center of activity. Nodes correspond to acoustic receivers grouped into regions; see Fig. 3 for region abbreviations. Lines that cross land indicate that individuals moved between the 2 nodes but were not detected on any intermediate nodes

Table 2. Node metrics of the network for all tagged smalltooth sawfish Pristis pectinata. Degree is defined as the number of connections a region has to other regions. Strength is a calculation that takes into account the number of individual movements taken between regions. Page rank centrality is a measure of region importance in the network. Betweenness is a measurement of the number of times a region can be found on the shortest path between 2 regions within the network

\begin{tabular}{|lcccc|}
\hline Regions & Degree & Strength & $\begin{array}{c}\text { Page rank } \\
\text { centrality }\end{array}$ & $\begin{array}{c}\text { Between- } \\
\text { ness }\end{array}$ \\
\hline Apalachee Bay & 2 & 2 & 0.02 & 0 \\
Tampa Bay & 9 & 12 & 0.03 & 34.1 \\
Venice & 6 & 8 & 0.02 & 8 \\
Peace River & 11 & 35 & 0.04 & 12 \\
Caloosahatchee & 13 & 280 & 0.25 & 29.4 \\
$\quad$ River & & & & \\
Boca Grande & 12 & 19 & 0.04 & 60.3 \\
Ten Thousand & 7 & 29 & 0.04 & 0 \\
$\quad$ Islands & & & & \\
Everglades & 10 & 76 & 0.9 & 13.9 \\
$\quad$ National Park & & & & \\
Florida Keys & 19 & 341 & 0.32 & 35.8 \\
Biscayne Bay & 4 & 11 & 0.02 & 0 \\
West Palm Beach & 6 & 23 & 0.04 & 1.2 \\
Cape Canaveral & 14 & 31 & 0.06 & 50.8 \\
North Florida & 2 & 2 & 0.02 & 0 \\
Georgia & 1 & 1 & 0.02 & 0 \\
\hline
\end{tabular}




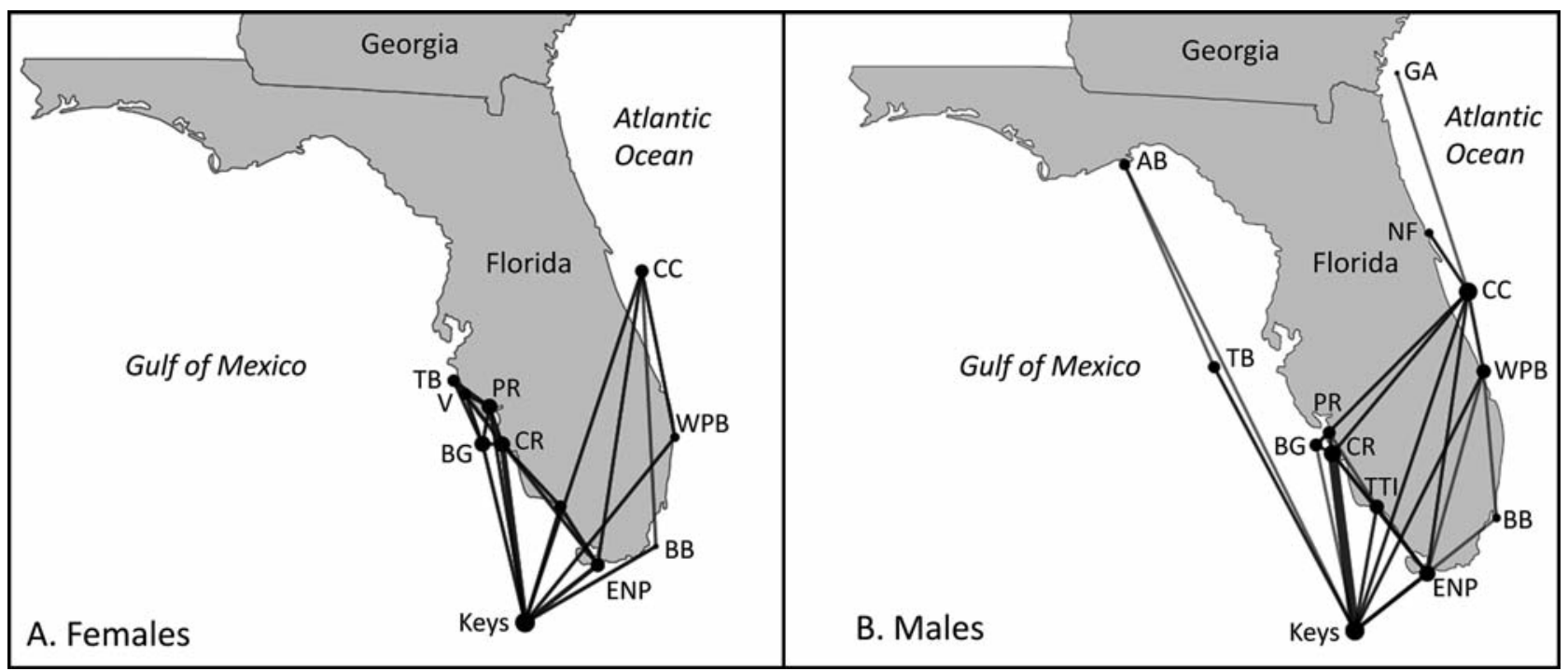

Fig. 6. Sex-specific network graphs for smalltooth sawfish Pristis pectinata $(A)$ females $(n=24)$ and $(B)$ males $(n=19)$

Table 3. Node metrics of the networks for female and male smalltooth sawfish Pristis pectinata. D: degree; S: strength; PRC: page rank centrality; B: betweenness (for an explanation of the metrics see Table 2). Blank cells indicate that that metric was incalculable in the observed network

\begin{tabular}{|c|c|c|c|c|c|c|c|c|}
\hline \multirow[t]{2}{*}{ Regions } & \multicolumn{4}{|c|}{ Females } & \multicolumn{4}{|c|}{-Males- } \\
\hline & $\mathrm{D}$ & $\mathrm{S}$ & PRC & B & $\mathrm{D}$ & $\mathrm{S}$ & PRC & B \\
\hline Apalachee Bay & & & & 2 & 2 & 0.02 & 0 & \\
\hline Tampa Bay & 6 & 8 & 0.04 & 5.1 & 3 & 4 & 0.02 & 10 \\
\hline Venice & 6 & 8 & 0.03 & 3.3 & & & & \\
\hline Peace River & 10 & 26 & 0.07 & 9.6 & 4 & 0 & 0.02 & 0 \\
\hline Caloosahatchee River & 10 & 97 & 0.22 & 7.3 & 11 & 207 & 0.28 & 20.2 \\
\hline Boca Grande & 10 & 13 & 0.05 & 27.6 & 6 & 6 & 0.02 & 21.5 \\
\hline Ten Thousand Islands & 6 & 16 & 0.05 & 0.5 & 6 & 14 & 0.04 & 0 \\
\hline Everglades National Park & 8 & 38 & 0.1 & 6.7 & 9 & 38 & 0.08 & 22.26 \\
\hline Florida Keys & 16 & 128 & 0.31 & 40.3 & 15 & 237 & 0.34 & 61.6 \\
\hline Biscayne Bay & 3 & 9 & 0.04 & 0 & 2 & 2 & 0.02 & 6.5 \\
\hline West Palm Beach & 4 & 7 & 0.03 & 0 & 6 & 16 & 0.04 & 12 \\
\hline Cape Canaveral & 7 & 8 & 0.04 & 26.8 & 13 & 23 & 0.07 & 58 \\
\hline North Florida & & & & 2 & 2 & 0.02 & 0 & \\
\hline Georgia & & & & & 1 & 1 & 0.02 & 0 \\
\hline
\end{tabular}

movements of both life stages were not significantly different (Fig. 7, Table 4). The Florida Keys node was important to both life stages, whereas the Everglades National Park node was important in the movement network of the mature sawfish, but the Caloosahatchee River node was more important in the movement network of the immature sawfish. One observable difference between the 2 life stages is the nodes they used when traveling. The Florida Keys, Cape Canaveral, and Tampa Bay regions serve as important movement corridors for mature sawfish, while the Boca Grande region is an important movement corridor for immature sawfish. A Wilcoxon rank test also showed no significant difference in mean degree $(p=0.751)$, betweenness $(\mathrm{p}=0.188)$, or page rank centrality $(\mathrm{p}=$ 0.734 ) between immature and mature sawfish, indicating that there was no difference in their movements.

When comparing the networks by season, the highest number of regions were used in spring and summer and the lowest number of regions were used in winter (Fig. 8); however, the nodes that were used each season seemed to be used in similar ways (Fig. 8, Table 5). The Florida Keys node was the more important node in every season except for summer, when the Caloosahatchee River node was more important. Not only did the sawfish not spend as much time in the Florida Keys in the summer, but they did not use it as a movement corridor either. A Kruskal-Wallis rank sum test showed no significant difference in mean degree ( $p=0.364)$, betweenness $(p=0.461)$, or page rank centrality ( $p=0.414$ ) across seasons. In general, region use seemed to be comparable for all individuals, despite demographic differences. Although some regions were used consistently throughout the year, the time spent in these areas varied from season to season. 


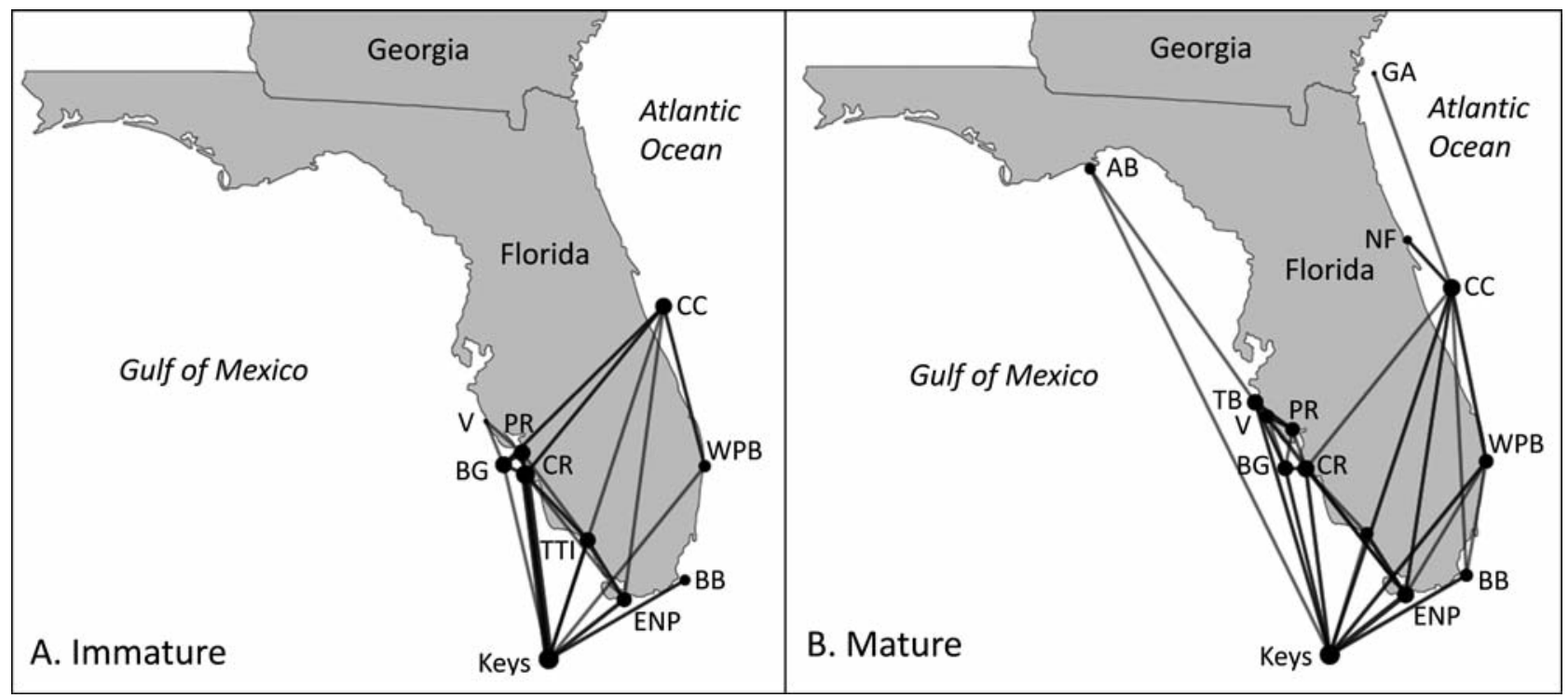

Fig. 7. Age-specific network graphs for smalltooth sawfish Pristis pectinata $(\mathrm{A})$ immature $(\mathrm{n}=29)$ and $(\mathrm{B})$ mature $(\mathrm{n}=14)$

Table 4. Node metrics of the networks for immature and mature smalltooth sawfish Pristis pectinata. D: degree; S: strength; PRC: page rank centrality; B: betweenness (for an explanation of the metrics see Table 2). Blank cells indicate that that metric was incalculable in the observed network

\begin{tabular}{|c|c|c|c|c|c|c|c|c|}
\hline \multirow{2}{*}{ Regions } & \multicolumn{4}{|c|}{ - Immature - } & \multicolumn{4}{|c|}{ - Mature - } \\
\hline & $\mathrm{D}$ & $\mathrm{S}$ & $\mathrm{PRC}$ & B & $\mathrm{D}$ & $\mathrm{S}$ & $\mathrm{PRC}$ & B \\
\hline Apalachee Bay & & & & & 2 & 2 & 0.02 & 0 \\
\hline Tampa Bay & 0 & 0 & 0.01 & 0 & 9 & 12 & 0.07 & 40.7 \\
\hline Venice & 2 & 2 & 0.02 & 0 & 5 & 6 & 0.04 & 5.2 \\
\hline Peace River & 8 & 28 & 0.05 & 15 & 6 & 7 & 0.05 & 9 \\
\hline Caloosahatchee River & 11 & 261 & 0.32 & 13.7 & 10 & 19 & 0.08 & 16.2 \\
\hline Boca Grande & 8 & 9 & 0.05 & 22 & 8 & 10 & 0.06 & 33.5 \\
\hline Ten Thousand Islands & 7 & 21 & 0.05 & 8 & 4 & 8 & 0.04 & 0 \\
\hline Everglades National Park & 6 & 32 & 0.06 & 0 & 10 & 44 & 0.08 & 43.1 \\
\hline Florida Keys & 13 & 273 & 0.35 & 16 & 16 & 68 & 0.24 & 47.8 \\
\hline Biscayne Bay & 2 & 2 & 0.02 & 0 & 4 & 9 & 0.04 & 0 \\
\hline West Palm Beach & 3 & 4 & 0.03 & 3 & 6 & 19 & 0.07 & 4.2 \\
\hline Cape Canaveral & 8 & 8 & 0.05 & 26.8 & 11 & 23 & 0.09 & 34 \\
\hline North Florida & & & & & 2 & 2 & 0.02 & 0 \\
\hline Georgia & & & & & 1 & 1 & 0.02 & 0 \\
\hline
\end{tabular}

\section{DISCUSSION}

This study is the result of a collaborative, multiyear, multi-institutional project that made use of expansive acoustic array networks. To date, it is the largest movement study conducted on large juvenile and adult smalltooth sawfish. The large size range and even sex distribution of individuals tagged allowed for expansion upon previous observations (Papastamatiou et al. 2015). Large juvenile and adult sawfish of both sexes made migrations along both the
Gulf and Atlantic coasts of Florida, suggesting that neither size nor sex can be used as a predictor of migration. We identified 3 major regions that appear to be important for large sawfish migrations: (1) the Gulf coast around Boca Grande, (2) the Atlantic coast around Cape Canaveral, and (3) south Florida around the Florida Keys. Identification of these high-use areas can lead to these regions being further evaluated as potential Critical Habitat for large juvenile and adult smalltooth sawfish. Additionally, these areas may be good starting points for establishing permanent receiver arrays that could be used to assess habitat use by this endangered species over predicted decadal-scale recovery timelines.

Overall node metrics coupled with a very small proportion of acoustic detections $(<1 \%)$ indicate that Biscayne Bay, West Palm Beach, Venice, and Tampa Bay are not currently areas of high-use for smalltooth sawfish, despite the presence of suitable habitats in these locations. Limited detections in both number and frequency from Biscayne Bay and West Palm Beach are rather surprising given their location between the core population in southwest Florida and the long-term stopover site identified offshore of Cape Canaveral. Despite the conclusion of McDonnell et al. (2020) indicating potential recovery and possible fidelity of smalltooth 


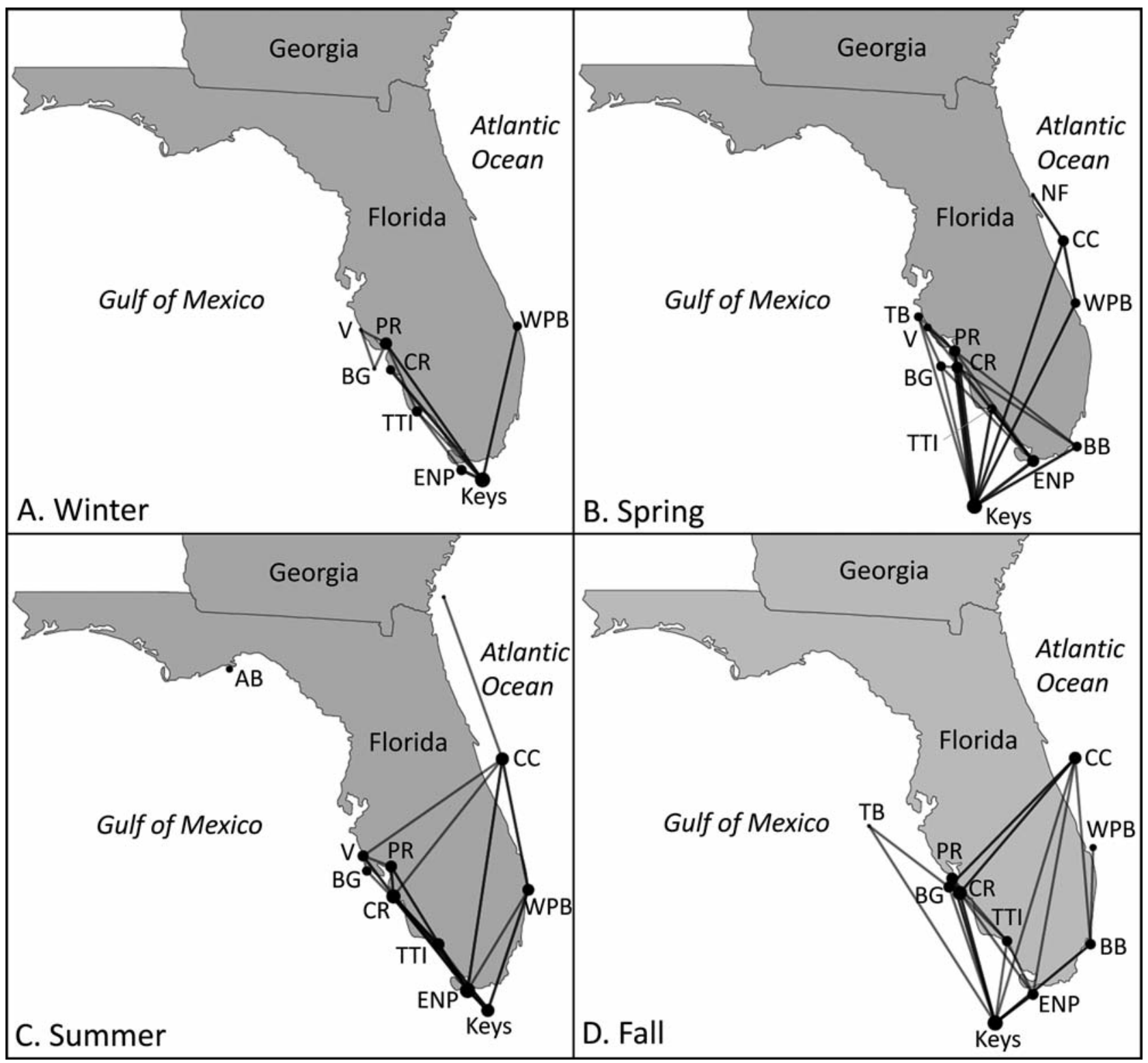

Fig. 8. Seasonal network graphs for smalltooth sawfish Pristis pectinata in (A) winter (December-February), (B) spring (March-May), (C) summer (June-August), and (D) fall (September-November)

sawfish in Biscayne Bay, detections there were minimal in comparison to locations further south and north, indicating that the Biscayne Bay region serves only as a short-term stopover site as individuals migrate along the east coast of Florida.

More than half $(n=25)$ of the smalltooth sawfish tagged in this study left the region in which they were tagged and traveled to other regions. Within this group of apparent migrants, $57 \%$ were large juveniles and $43 \%$ were adults. Although movements could not conclusively be categorized as migratory due to the limited temporal scale, the use of
$10 \mathrm{yr}$ tags in this study will allow for a clearer determination in the future. For the purpose of this study, individuals were categorized based on the current evidence. Both immature and mature individuals of both sexes migrated. Movements, with a few exceptions, occurred around the same times of year and appeared cyclical. This indicates a seasonal migration, where some members of the population migrate north in the summer and return south in the winter. Papastamatiou et al. (2015) found that mature male sawfish began moving north in May or June, which is the same time most sawfish were recorded 
Table 5. Node metrics of the networks for each season. Winter: December-February; Spring: March-May; Summer: JuneAugust; Fall: September-November. D: degree; B: betweenness; PRC: page rank centrality (for an explanation of the metrics see Table 2). Blank cells indicate that that metric was incalculable in the observed network

\begin{tabular}{|c|c|c|c|c|c|c|c|c|c|c|c|c|}
\hline \multirow[t]{2}{*}{ Region } & \multicolumn{3}{|c|}{ - Winter- } & \multicolumn{3}{|c|}{-Spring } & \multicolumn{3}{|c|}{-Summer - } & \multicolumn{3}{|c|}{ - Fall } \\
\hline & $\mathrm{D}$ & B & $\mathrm{PRC}$ & $\mathrm{D}$ & B & PRC & $\mathrm{D}$ & B & PRC & $\mathrm{D}$ & B & $\mathrm{PRC}$ \\
\hline Apalachee Bay & & & & & & 0 & 0 & 0.02 & & & & \\
\hline Tampa Bay & & & & 3 & 23.5 & 0.02 & 4 & 13 & 0.03 & 2 & 0 & 0.02 \\
\hline Venice & 6 & 0.04 & & 7.5 & 0.02 & 3 & 16.5 & 0.02 & 2 & & & 2 \\
\hline Caloosahatchee River & 2 & 0 & 0.13 & 7 & 5 & 0.26 & 9 & 14.6 & 0.27 & 10 & 7.8 & 0.13 \\
\hline Peace River & 5 & 24 & 0.08 & 7 & 42 & 0.07 & 5 & 25.4 & 0.03 & 6 & 1.5 & 0.06 \\
\hline Boca Grande & 2 & 6 & 0.05 & 4 & 23.5 & 0.02 & 2 & 0 & 0.02 & 7 & 3.7 & 0.07 \\
\hline Ten Thousand Islands & 3 & 6 & 0.07 & 4 & 0 & 0.04 & 6 & 12.3 & 0.06 & 4 & 2.8 & 0.07 \\
\hline Everglades National Park & 3 & 0 & 0.2 & 8 & 16 & 0.08 & 11 & 32.7 & 0.1 & 5 & 6 & 0.18 \\
\hline Florida Keys & 9 & 32 & 0.38 & 15 & 64 & 0.3 & 7 & 6.5 & 0.27 & 12 & 24 & 0.26 \\
\hline Biscayne Bay & & & & 4 & 8.5 & 0.03 & & & & 4 & 7 & 0.08 \\
\hline West Palm Beach & 2 & 0 & 0.04 & 4 & 0 & 0.06 & 5 & 2.8 & 0.06 & 1 & 0 & 0.02 \\
\hline Cape Canaveral & & & & 6 & 24.5 & 0.08 & 7 & 11.3 & 0.08 & 7 & 10 & 0.11 \\
\hline North Florida & & & & 0 & 0.03 & & & & & & & 2 \\
\hline Georgia & & & & & & & 1 & 0 & 0.03 & & & \\
\hline
\end{tabular}

leaving the Florida Keys region in the current study. Papastamatiou et al. (2015) lacked representation of females, but the current study revealed that the migrant sawfish group is made up of both sexes moving at similar times. Papastamatiou et al. (2015) did not observe southerly movements because no data were collected during the fall or winter, likely due to the use of external tags that led to diminished tag retention. In our study, fall and winter was the time when sawfish were observed moving southward.

While this large-scale study covered most of the Florida coastline and had a relatively large sample size, there were some limitations. Due to the nature of acoustic telemetry, data were limited by detection range and receiver coverage. The detection range for receivers is variable and can range from a radius of $<100 \mathrm{~m}$ to more than $500 \mathrm{~m}$ depending on many factors (Collins et al. 2008, Huveneers et al. 2016, Mourier et al. 2017), but previous studies have shown that the proportion of transmissions received begins to drop rapidly approximately $400 \mathrm{~m}$ from a receiver (Kessel et al. 2014). Therefore, areas with high receiver density, where detection ranges of receivers sometimes overlap and thus cover a larger area, were more likely to detect sawfish. Interestingly, longer tracking times did not always correlate with increased detections. These individual differences are likely best explained by other factors, the most important being tagging location and receiver density. There is also potential bias associated with the different tag types. Tags used within the study were consistent within but not between tagging locations, thus it is difficult to draw conclusions among locations.
Within the network analysis there were gaps of coverage, likely due to sparse receiver coverage in certain areas and differences in receiver deployment times among institutions. Some sawfish moved long distances without encountering a receiver, and thus information about specific locations along their movement track was missing. These missing data were interpolated based on reasonable paths that could have been taken and general travel speed of sawfish. Targeted areas for receiver arrays such as northwest Florida Bay and Charlotte Harbor provided good coverage, whereas other arrays designed for other studies may not be in ideal locations to detect sawfish. With increased receiver coverage, particularly north of Tampa Bay on the Gulf coast and Cape Canaveral on the east coast, as well as increased data sharing within networks to identify zero detection receivers, a clearer picture of sawfish movements may be developed.

Both large juvenile and adult sawfish were observed migrating north along the Gulf and Atlantic coasts of Florida. Both the male and female networks showed movement north of the Florida Bay area, and seasonal networks confirmed this northward movement to be in the spring and summer. The large juveniles and adults appear to be using the northwest portions of Florida Bay as well as the deeper shelfedge habitats of the Florida Reef Tract to the Marquesas. This information suggests that the Ten Thousand Islands/Everglades Unit of designated Critical Habitat for small juveniles could be extended to include coastal to shelf edge areas of the Florida Keys and Marquesas for large juveniles and adults. Addi- 
tionally, the area off Cape Canaveral seems to be an important area for larger smalltooth sawfish and could also be examined further for possible Critical Habitat designation. Based on public encounter data, Waters et al. (2014) also observed that large juveniles and adults were concentrated in many of the areas noted in the current study, such as Florida Bay, the Atlantic coast of the Florida Keys, and along the coast of southeast Florida. However, no observations were made regarding smalltooth sawfish off Cape Canaveral. Waters et al. (2014) also observed a similar temporal pattern, with individuals being found in Charlotte Harbor mostly in the summer, in Ten Thousand Islands National Wildlife Refuge from March to August, in Florida Bay in March, the Florida Keys year-round, and in southeast Florida in June and September. These areas are more than just transitory habitats, as there was high use of Everglades National Park and Florida Keys regions throughout the year. Cape Canaveral appeared to be the final destination for most individuals traveling north along the east coast, and it was an extended stopover point for those individuals traveling even further north. This pattern is similar to the distribution found by Wiley \& Simpfendorfer (2010), who also found that the largest sawfish $(>2 \mathrm{~m})$ were encountered between March and September along the Florida Panhandle, Cape Canaveral, and Georgia coasts. Although the sawfish in that study used regions dominated by mangroves, likely only briefly for giving birth or mating, our data suggest these large sawfish do not use the mangrove shorelines heavily and associate more with deeper coastal habitats.

The greater Charlotte Harbor Estuary Unit of designated Critical Habitat for small juveniles also appears to be an important region for large juveniles and adults and could be further evaluated as Critical Habitat for these life stages. Early in their ontogeny, smalltooth sawfish born in Charlotte Harbor display fidelity to their nurseries (Caloosahatchee River and Peace River) and begin to leave the area as they mature, sometimes returning later (Feldheim et al. 2017, Brame et al. 2019). This ontogenetic shift is supported by the movements of the migrant sawfish tagged in the Charlotte Harbor area that were significantly larger than the resident sawfish. Although sawfish spent less time in Charlotte Harbor as they matured, they spent portions of the year in this area, indicating that it remains important throughout ontogeny. Female sawfish have been shown to return to the same areas to give birth (Feldheim et al. 2017). This may explain why larger females continue to spend a large portion of the year in the Charlotte Harbor area.
Sawfish born in Everglades National Park may exhibit a similar pattern to those born in Charlotte Harbor, but the size range of individuals in this study was insufficient to see that shift. There was no discernable difference in size between the resident and migrant sawfish tagged in the Florida Keys, and thus other factors must contribute to whether they migrate or not. The outcome of migration could be based on sex, breeding status, body condition, or inter-annual variation in climatic factors. One hypothesis for the migration is that the females, which reproduce biennially in Florida (Feldheim et al. 2017), migrate to avoid males outside of their mating periods, as interactions with males may be costly or dangerous. Although there is evidence of sexual segregation in Florida Bay (Papastamatiou et al. 2015), the migrations observed in this study were not limited to females. Both juvenile and adult males participated in the seasonal migration, indicating that there may be other cues that initiate migration in some individuals. Considering thermal performance (Lear et al. $2019 b)$, it is possible that the water temperatures in the Florida Keys may become too warm for some individuals, triggering movement northward. As water temperatures warm in the summer, some sawfish may seek out cooler waters. However, deeper shelf-edge waters along the Florida Keys are tempered from seasonal temperature swings and also may serve as thermal refugia for large smalltooth sawfish both in winter and summer. It is possible that the northern movements in summer may be more related to mating than abiotic constraints, though this has not been well researched. Although anecdotal observations were made by Bigelow \& Schroeder (1953) about historic smalltooth sawfish migrations, this is a poorly researched area.

In addition to identifying predictors of whether or not a sawfish will migrate, it is important to examine spatial migratory patterns. One hypothesis is that migration depends on where the sawfish was born. Nursery grounds for the smalltooth sawfish exist in both units of small juvenile Critical Habitat (Norton et al. 2012). Adult females are known to return to specific Charlotte Harbor nursery grounds (Feldheim et al. 2017). The same could be true for sawfish born elsewhere. This hypothesis cannot be tested without genetic information linking individuals to nursery grounds while simultaneously monitoring movements to and from the nurseries with acoustic receivers. This hypothesis may be challenged by the 2 individuals ( 1 female and 1 male) that used portions of both coasts, particularly the individual which used both coasts in the same year, although it is possible these 
exploratory journeys do not represent the main migration pattern. If it were a product of nursery grounds, the movement should be consistent up one coast, and rarely the other. The tags deployed in this study, particularly those with 10 yr battery life, should continue to be monitored to determine if coast selection is consistent, or if it changes. Factors affecting the outcome of which coast smalltooth sawfish migrate along can then be further examined in relation to genetics, water temperature, and other environmental conditions across the years.

In conclusion, on the basis of the results of this study and many years of encounter data from the public, we have identified areas frequently used by large juvenile and adult sawfish, which may be vital for the species' persistence. However, further studies will still need to investigate the physical and biological features of these areas to determine if any are essential for these larger life stages before Critical Habitat designations can be made. Critical Habitat designations offer legal protections for areas deemed necessary to the recovery of the species. Identifying these important areas is necessary to support growth and range expansion of the population. The 2 units of Critical Habitat that have been designated for small juvenile smalltooth sawfish (Norton et al. 2012) also appear to serve as important habitat for large juveniles and adults, though use of these areas by larger sawfish extends beyond current boundaries. For example, the nearshore coastal waters off Charlotte Harbor from shore to depths of at least $10 \mathrm{~m}$ should be investigated as Critical Habitat for the larger life stages of smalltooth sawfish. In addition, the areas surrounding the entire Florida Keys past the Marquesas from shore to depths of at least $70 \mathrm{~m}$ (Poulakis \& Seitz 2004) should be assessed for possible inclusion in the Everglades National Park unit to account for the large activity spaces documented there. The current study also identified one additional area that may be of importance to the larger size classes of smalltooth sawfish. The area off the east coast of Florida from shore to depths of at least $20 \mathrm{~m}$ that spans from Cape Canaveral to at least the Jupiter area could be evaluated as potential Critical Habitat in the future, given documented encounters of large sawfish by divers (Waters et al. 2014) and the results of our study. Future efforts should focus on these identified high-use areas to determine underlying habitat features. Future studies should also consider genetics in coordination with acoustic telemetry techniques to understand the role of philopatry in influencing migration patterns between the identified high-use areas.
Acknowledgements. We thank all of the researchers who shared acoustic data that were detected on their receivers including K. Bassos-Hull, B. Bowers, J. Brownscomb, A. Collins, A. Fox, L. Griffin, N. Hammerschlag, C. Kalinowsky, J. Locascio, W. Pratt, J. Rehage, and J. Young. We thank M. Ajemian and M. McCallister for opportunistically tagging the 2 sawfish off the east coast under Endangered Species Permit no. 15802. We thank A. Wooley and A. Court for assistance tagging sawfish in Charlotte Harbor, and personnel of the NOAA Fisheries Panama City Laboratory for field assistance. A. Brame and A. Wooley improved earlier versions of the manuscript. This work was supported by funding from the US Department of Commerce, National Science Foundation Graduate Research Fellowship Program under grant no. 1449440, NOAA National Marine Fisheries Service through section 6 (Cooperation with the States) of the US ESA under grant award no. NA16NMF4720062 to the Florida Fish and Wildlife Conservation Commission, funding to Florida State University (FSU) through the Northern Gulf Institute and the NOAA Fisheries Office of Protected Resources as well as the Disney Conservation Fund. This research was conducted under Endangered Species Permit nos. 15802, 17787, and 22078 issued by NOAA Fisheries. Sawfish tagged by FSU were tagged under approval of FSU IACUC Protocol 1718. The senior author thanks N. Underwood, S. Burgess, and J. Elsner for their support of this work and assistance with $\mathrm{R}$ coding. The scientific results and conclusions, as well as any views or opinions expressed herein, are those of the authors and do not necessarily reflect those of NOAA or the Department of Commerce.

\section{LITERATURE CITED}

Bigelow HB, Schroeder WC (1953) Fishes of the western North Atlantic, Part II. Sawfishes, guitarfishes, skates, rays, and chimaeroids. Mem Sears Found Mar Res, Yale University, New Haven, CT

Brame AB, Wiley TR, Carlson JK, Fordham SV and others (2019) Biology, ecology, and status of the smalltooth sawfish Pristis pectinata in the USA. Endang Species Res 39: 9-23

Carlson J, Wiley T, Smith K (2013) Pristis pectinata (errata version published 2019). The IUCN Red List of Threatened Species 2013:e.T18175A141791261. http://dx.doi.org/ 10.2305/IUCN.UK.2013-1.RLTS.T18175A141791261.en (accessed 6 June 2019)

* Carlson JK, Gulak, SJB, Simpfendorfer CA, Grubbs RD, Romine JG, Burgess GH (2014) Movement patterns and habitat use of smalltooth sawfish, Pristis pectinata, determined using pop-up satellite archival tags. Aquat Conserv 24:104-117

Collins AB, Heupel MR, Simpfendorfer CA (2008) Spatial distribution and long-term movement patterns of cownose rays Rhinoptera bonasus within an estuarine river. Estuar Coast 31:1174-1183

Csardi G, Nepusz T (2006) The igraph software package for complex network research. InterJournal, Complex Systems, 1695. https://igraph.org

* Dulvy NK, Fowler SL, Musick JA, Cavanagh RD and others (2014) Extinction risk and conservation of the world's sharks and rays. eLife 3:e00590

Feldheim KA, Fields AT, Chapman DD, Scharer RM, Poulakis GR (2017) Insights into reproduction and behavior of the smalltooth sawfish Pristis pectinata. Endang Species Res 34:463-471 
Grubbs RD (2010) Ontogenetic shifts in movements and habitat use. In: Carrier JC, Musick JA, Heithaus MR (eds) Sharks and their relatives II: biodiversity, adaptive physiology, and conservation. CRC Press, Boca Raton, FL, p 319-350

Hollensead LD, Grubbs RD, Carlson JK, Bethea DM (2016) Analysis of fine-scale daily movement patterns of juvenile Pristis pectinata within a nursery habitat. Aquat Conserv 26:492-505

Hollensead LD, Grubbs RD, Carlson JK, Bethea DM (2018) Assessing residency time and habitat use of juvenile smalltooth sawfish using acoustic monitoring in a nursery habitat. Endang Species Res 37:119-131

Huveneers C, Simpfendorfer CA, Kim S, Semmens JM and others (2016) The influence of environmental parameters on the performance and detection range of acoustic receivers. Methods Ecol Evol 7:825-835

Kahle D, Wickham H (2013) ggmap: spatial visualization with ggplot2. The R Journal 5:144-161. http://journal.rproject.org/archive/2013-1/kahle-wickham.pdf

Kessel ST, Cooke SJ, Heupel MR, Hussey NE, Simpfendorfer CA and others (2014) A review of detection range testing in aquatic passive acoustic telemetry studies. Rev Fish Biol Fish 24:199-218

Lear KO, Poulakis GR, Scharer RM, Gleiss AC, Whitney NM (2019a) Fine-scale behavior and habitat use of the endangered smalltooth sawfish (Pristis pectinata): insights from accelerometry. Fish Bull 117:348-359

Lear KO, Whitney NM, Morgan DL, Brewster LR and others (2019b) Thermal performance responses in free-ranging elasmobranchs depend on habitat use and body size. Oecologia 191:829-842

McDonnell LH, Jackson TL, Burgess GH, Phenix L and others (2020) Saws and the city: smalltooth sawfish Pristis pectinata encounters, recovery potential, and research priorities in urbanized coastal waters off Miami, Florida, USA. Endang Species Res 43:543-553

Mourier J, Bass NC, Guttridge TL, Day J, Brown C (2017) Does detection range matter for inferring social networks in a benthic shark using acoustic telemetry? Royal Soc Open Sci 4:170485

NMFS (US National Marine Fisheries Service) (2009) En-

Editorial responsibility: Brendan Godley,

University of Exeter, Cornwall Campus, UK dangered and threatened species; critical habitat for the endangered distinct population segment of smalltooth sawfish. Fed Regist 74:45353-45378

* Norton SL, Wiley TR, Carlson JK, Frick AL, Poulakis GR, Simpfendorfer CA (2012) Designating critical habitat for juvenile endangered smalltooth sawfish in the United States. Mar Coast Fish 4:473-480

Papastamatiou YP, Grubbs RD, Imhoff JL, Gulak SJB, Carlson JK, Burgess GH (2015) A subtropical embayment serves as essential habitat for sub-adults and adults of the critically endangered smalltooth sawfish. Glob Ecol Conserv 3:764-775

Poulakis GR, Seitz JC (2004) Recent occurrence of the smalltooth sawfish, Pristis pectinata (Elasmobranchiomorphi: Pristidae), in Florida Bay and the Florida Keys, with comments on sawfish ecology. Fla Sci 67:27-35

*Poulakis GR, Stevens PW, Timmers AA, Wiley TR, Simpfendorfer CA (2011) Abiotic affinities and spatiotemporal distribution of the endangered smalltooth sawfish, Pristis pectinata, in a south-western Florida nursery. Mar Freshw Res 62:1165-1177

Poulakis GR, Stevens PW, Timmers AA, Stafford CJ, Simpfendorfer CA (2013) Movements of juvenile endangered smalltooth sawfish, Pristis pectinata, in an estuarine river system: use of non-main-stem river habitats and lagged responses to freshwater inflow-related changes. Environ Biol Fishes 96:763-778

R Core Team (2019) R: a language and environment for statistical computing. R Foundation for Statistical Computing, Vienna

Seitz JC, Poulakis GR (2006) Anthropogenic effects on the smalltooth sawfish (Pristis pectinata) in the United States. Mar Pollut Bull 52:1533-1540

Waters JD, Coelho R, Fernandez-Carvalho J, Timmers AA and others (2014) Use of encounter data to model spatiotemporal distribution patterns of endangered smalltooth sawfish, Pristis pectinata, in the western Atlantic. Aquat Conserv 24:760-776

*Wiley TR, Simpfendorfer CA (2010) Using public encounter data to direct recovery efforts for the endangered smalltooth sawfish Pristis pectinata. Endang Species Res 12: 179-191

Submitted: August 1, 2020; Accepted: October 26, 2020 Proofs received from author(s): January 18, 2021 